\title{
Associations of Tabanidae (Diptera) Larvae with Plant Species in Salt Marshes, Carteret County, North Carolina ${ }^{1}$
}

\author{
J. C. DUKES, T. D. EDWARDS, AND R. C. AXTELL ${ }^{2}$ \\ Department of Entomology, North Carolina State Univ., Raleigh 27607
}

ABSTRACT

Larvae of Tabanus nigrovittatus Macquart, Chrysops fuliginosus Wiedemann and $C$. atlanticus Pechuman were recovered most often and in greatest abundance in regularly flooded areas of salt marshes with nearly uniform stands of Spartina alterniflora Loisel (smooth cordgrass). Areas of $S$. cynosuroides (L.) Roth. (giant cordgrass), Distichlis spicata (L.) Greene (salt grass), and Juncus roemerianus Scheele (black needle rush) yielded decreasing numbers of tabanid larvae (in that order). In mixed vegetation, as the proportion of other vegetation increased and $S$. alterniflora decreased, the numbers of tabanid larvae declined.

Coastal and estuarine marshes are important sources of nutrients (Cooper 1969) but are also excellent habitats for the immature stages of certain species of biting flies (Tabanidae, Ceratopogonidae, and Culicidae) affecting man and animals. The coastal area of North Carolina has extensive salt marshes which produce many important pest species of Diptera. Among these are several species of Tabanidae which are numerous enough on occasions to be considered major pests. To develop management programs for these biting flies we need to be able to delineate as precisely as possible the locations within the marsh which are producing the majority of the pest population. Correlation of the abundance of tabanid larvae with the type of plant cover would allow rapid preliminary estimations of the potential tabanid population in an area.

Larval Tabanidae are generally associated with wet or damp soil, sand, or decomposing vegetation in the vicinity of water (Teskey 1962). The salt marsh species are usually found in the top 4 in. of sod according to Wall and Jamnback (1957). In Massachusetts (Bailey 1948, Wall and Doane 1960), tabanid larvae were found widely distributed in the marsh sod and they were most abundant where there was a cover of plants. According to Bailey (1948) larvae of Tabanus nigrovittatus Macquart rarely occurred in areas of standing water but were generally abundant in areas where Spartina alterniflora Loisel and especially $S$. patens (Ait.) Muhl. formed the sod. Therefore, he concluded that ditched marshes were more favorable for $T$. nigrovittatus because more extensive areas were available for the growth of these grasses.

In New Jersey, Rockel (1969) and Rockel and Hansens (1970 a, b) used a chemical larvicide and emergence traps to determine the locations of tabanid larvae in the marsh. They recovered larvae of

${ }^{1}$ This research was supported in part by NOAA, Office of Sea Grant, U. S. Department of Commerce, under Grant No. 2-35178. The U. S. Government is authorized to produce and distribute reprints for governmental purpose not withstanding any copyright notation that may appear hereon. Paper No. 4114 of cultural Experiment Station. Received for publication 10 Aug. 1973.

${ }^{2}$ Research Associate, Research Technician and Professor, respectively.
T. nigrovittatus and Chrysops spp. in greatest numbers in locations below the mean highwater level on gently sloping banks with "tall" S. alterniflora (about $2 \mathrm{ft}$ high). T. lineola Fabricius and " $T$. sp. 3" (a variant of $T$. nigrovittatus) were recovered more frequently from higher soil elevations with "short" $S$. alternifiora. Further larval sampling in New Jersey (Freeman and Hansens 1972) has documented the general distribution of the larvae of the above species of Tabanidae in S. alterniflora marshes with the results being affected by the sampling method. Larviciding showed that " $T$. sp. 3" dominated the ditch banks and the typical larvae of $T$. nigrovittatus were primarily in the portions of the marsh with shorter grasses.

In North Carolina (Dukes et al. 1974), a fairly uniform distribution of $T$. nigrovittatus and $C$. fuliginosus larvae has been found in a uniform, regularly flooded $S$. alterniflora marsh characterized by little gradation in the heights of the grasses. All of the larval sites were below mean high tide level and flooded at every high tide.

A variety of marsh habitats are available for tabanid breeding in the coastal area of North Carolina. Carteret County has most of these types of marshes, 22,672 ha according to Perkins (1938), and was the locality of our investigations. Adams (1963) characterized the plants of the lower marsh by 3 associations, each dominated by a particular plant species and forming a zonal sequence from below the mean high tide level to the level of the spring high tides. Davis and Gray (1966) reported that the tidal marshes of Carteret County were simpler than Adam's classification. They described the marshes in 3 sequences. Sequence I is characterized by $S$. alterniflora to $S$. patens with only a band of drift separating the two. Sequence II consists of $S$. alterniflora to Juncus roemerianus Scheele to high marsh dominated by Distichles spicata (L.) Greene. In the 3 rd sequence, associated with creeks having low salinity and a high rate of silt deposition, Spartina cynosuroides (L.) Roth. replaces S. alterniflora in the lower zone and $J$. roemerianus occupies the higher zone.

The sequences described by Davis and Gray (1966) 
more closely compare with that found in the research areas we selected for sampling. Each area (Fig. 1) was chosen on the basis of the numbers and species of adult Tabanidae previously captured, the types of marsh vegetation, and the accessibility of the area.

\section{Materials and Methods}

Sampling in all areas was done in March and April 1972 by removing the soil and vegetative mat from an area $0.1 \mathrm{~m}^{2}$ and approximately $12 \mathrm{~cm}$ deep. The aerial portion of the vegetation was cut with pruning shears and removed. The soil was removed from the marsh using a post-hole digger. Each sample filled a 10-liter pail and weighed approximately $15 \mathrm{Kg}$. Samples were numbered consecutively with each sampling site marked with a numbered wooden stake. Each sample was recorded with the description of the vegetation and plotted on a scale map of the area. A tracked all-terrain vehicle was used to transport the samples from the marsh.

Larval samples were returned to a washing area located over a nearby tidal ditch. A wash-rack (Edwards et al. 1974) was used for removing the soil from the vegetative portion of the sample. The vegetative residue which remained following the washing procedure was held in Tullgren funnels heated by $60-\mathrm{w}$ incandescent bulbs to recover any additional tabanid larvae. The more mature larvae were placed singly into vials of natural media or glass beads (Roberts 1966) for rearing to the adult stage, or into $80 \%$ ethanol for preservation.

Adult specimens were identified by comparison to specimens identified by Dr. L. L. Pechuman (Cornell University, Ithaca, N.Y.) and by published descriptions (Jones and Anthony 1964, Pechuman 1972). Larvae were tentatively identified by reference to Jamnback and Wall (1959) and Teskey (1969) with final determinations by Dr. H. J. Teskey (Entomology Research Institute, Ottawa, Canada) or Dr. J. F. Freeman (Castleton State College, Castleton, Vt.).

\section{Newport River Marsh}

The research area was at the end of the Lake Shore Drive, Morehead City, N.C. The salt marsh plants in the area exhibited a definite zoned pattern from Spartina alterniflora to Distichlis spicata to Juncus roemerianus. Each vegetative type occurred in relatively pure stands separated by transition zones from one vegetation into the other. S. alterniflora (short and tall forms) was the most abundant vegetation. The tall form was along the ditches and nearest the river while the short form dominated the center portion of the marsh. Similar to the marshes in New Jersey (Rockel 1969), the density of the $S$. alterniflora increased as the elevation increased to the level of mean high tide and the height showed a reciprocal relationship with the sparser and taller

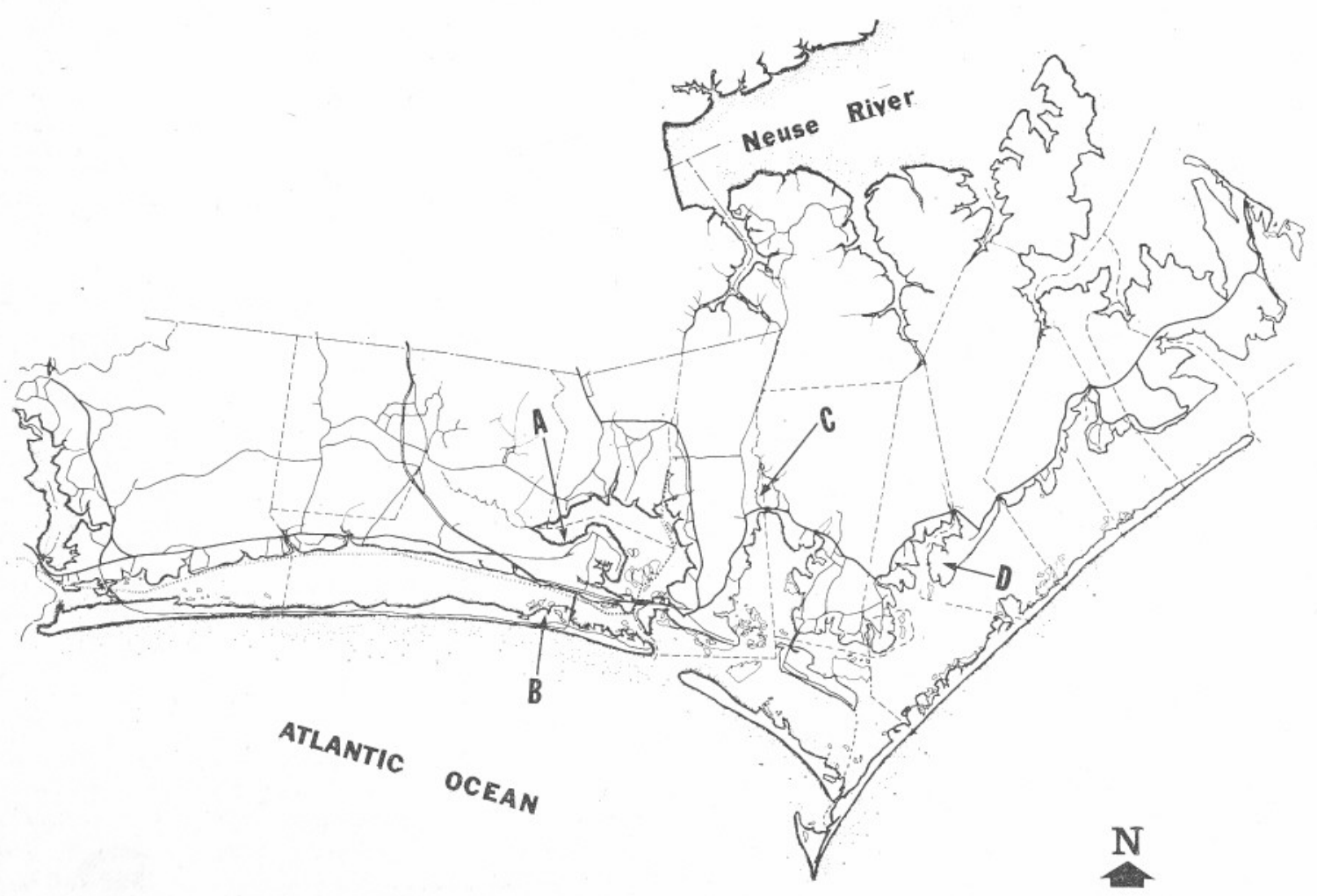

FIg. 1.-Map of Carteret County, North Carolina showing the locations of sample areas. $A=$ Newport River, $\mathrm{B}=$ Hoop Hole Creek, $\mathrm{C}=$ North River, and $\mathrm{D}=$ Davis Peninsula. 


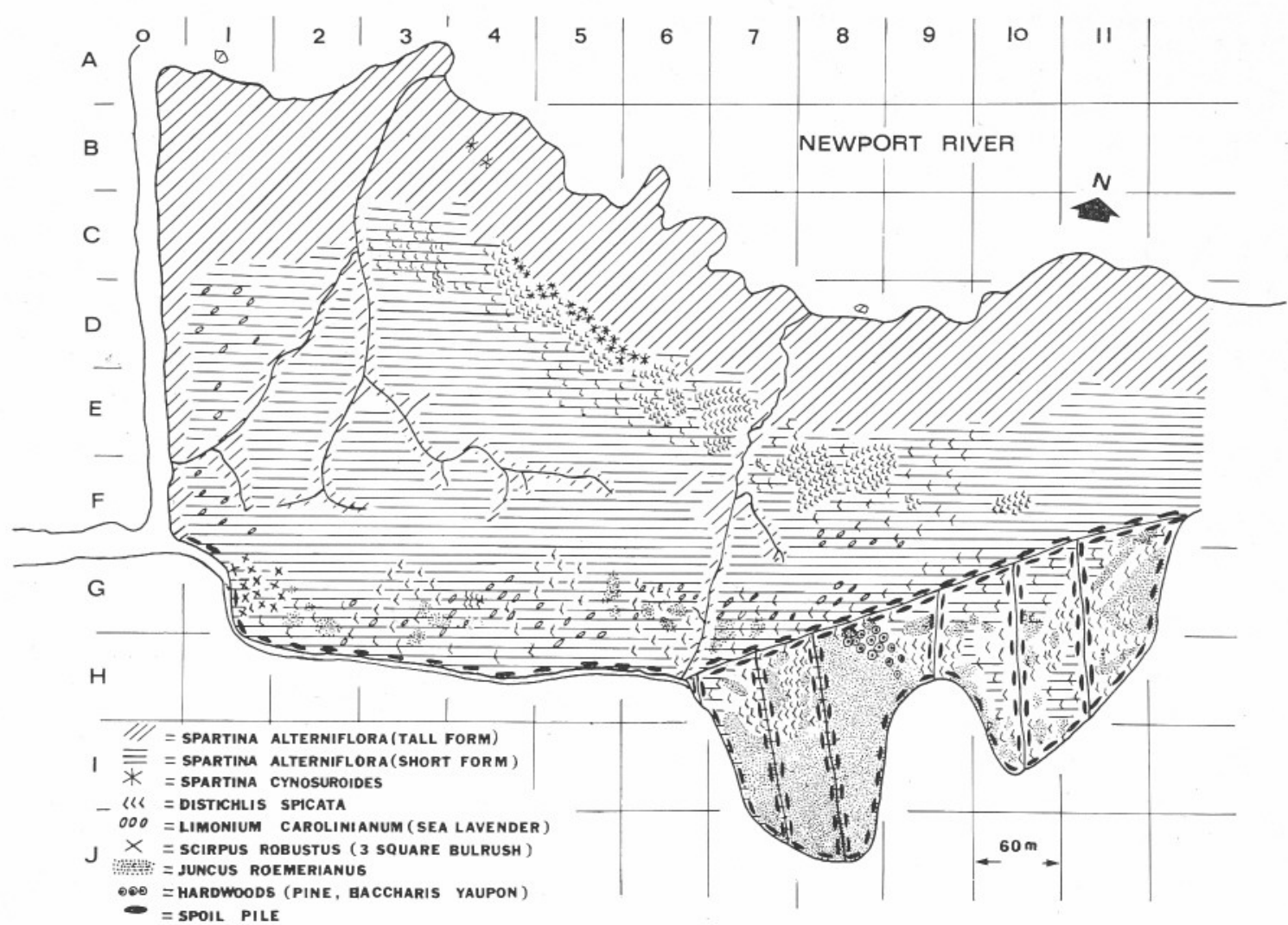

FIG. 2.-Diagram of Newport River Marsh, Carteret County, North Carolina showing distribution of various types of vegetation.

vegetation nearer the ditches and open water. The height differences in $S$. alterniflora apparently reflect differences in nutrition and soil salinity (Mooring et al. 1971). The research area contained 2.95 ha of marsh bordered by the Newport River on the northern side. A small band of high marsh shrubs separated the marsh from a large forest of hardwoods on the upper side. A peninsula of marsh extending back into the hardwood area was dominated by Juncus roemerianus. This area was ditched in the early 1960 's in a program to control salt marsh mosquitoes.

To facilitate sampling, the research area was surveyed and staked into a $60-\mathrm{m}$ square grid system. The primary vegetation occurring in each grid was mapped and recorded (Fig. 2, Table 1). Soil samples were taken in the various vegetative types.

The tide levels were recorded during most of the year using a Stevens type F (Leupold \& Stevens, Inc., Beaverton, Oregon 97005) water level recorder having an 8-day spring-driven clock. ${ }^{3}$ The semi-daily high and low tides differ by more than $3 \mathrm{ft}$. The study area was surveyed to determine elevation in relation to high tide level in the various vegetative zones. The degree of tidal inundation in relation to

${ }^{3}$ Tide level data in the text and table are given in feet because that unit is commonly used by engineers and marine scientists in the United States and the tide gauge equipment was calibrated in feet. monthly mean high tide levels is shown in Table 2 . The type of vegetation correlates with the degree of flooding, with tall $S$. alterniflora immersed the greatest and $D$. spicata the least.

\section{Hoop Hole Creek Marsh}

The study area was near Atlantic Beach on the sound side of Bogue Banks. The soil was sandy even in areas dominated by marsh vegetation. The area was chosen because of the sudden transitions from open water to Spartina alterniflora to Distichilis spicata to Juncus roemerianus to high marsh shrubs and hardwoods. The elevation gradient was steep and all vegetative types occurred within as little as $30 \mathrm{~m}$ from open water.

Samples were taken along 4 transects extending from the water into the high marsh shrubs. Samples were taken within $30 \mathrm{~cm}$ of the line and from each vegetative type.

\section{North River Marsh}

The research area at North River, near Beaufort, N. C. was an extensive marsh dominated by Juncus roemerianus. Approximately 30 ha (75 acres) of the marsh was crossed by a series of straight draglined ditches which were excavated in 1968 for mosquito control. The parallel ditches were evenly spaced $45 \mathrm{~m}$ apart and extended from the upland wooded 
Table 1.-Plants commonly found in 3 general areas of the Newport River salt marsh, Morehead City, N. C. Numbers show occurrence and order of abundance.

\begin{tabular}{|c|c|c|c|}
\hline Plant & $\begin{array}{l}\text { Low } \\
\text { Marsh }\end{array}$ & $\begin{array}{l}\text { High } \\
\text { Marsh }\end{array}$ & $\begin{array}{c}\text { Spoil } \\
\text { Piles } \\
\text { and } \\
\text { Mar- } \\
\text { gins }\end{array}$ \\
\hline $\begin{array}{l}\text { Spartina alterniflora } \text { Loisel } \\
\text { Smooth cordgrass }\end{array}$ & 1 & & \\
\hline $\begin{array}{l}\text { Distichlis spicata (L.) Greene } \\
\text { Salt grass }\end{array}$ & 2 & 2 & 2 \\
\hline $\begin{array}{l}\text { Limonium carolinianum (Walt.) } \\
\text { Britt. Sea-lavender }\end{array}$ & 3 & 3 & \\
\hline $\begin{array}{l}\text { Aster tenuifolius } \mathrm{L} . \\
\text { Salt marsh aster }\end{array}$ & 4 & & \\
\hline $\begin{array}{l}\text { Scirpus robustus Pursh }{ }^{\mathrm{a}} \\
\text { Three square bulrush }\end{array}$ & 5 & & \\
\hline $\begin{array}{l}\text { Spartina cynosuroides (L.) Roth } \\
\text { Giant cordgrass }\end{array}$ & 6 & & \\
\hline $\begin{array}{l}\text { Juncus roemerianus } \text { Scheele } \\
\text { Black needle rush }\end{array}$ & & 1 & \\
\hline $\begin{array}{l}\text { Borrichia frutescens (L.) Dc. } \\
\text { Sea ox eye }\end{array}$ & & 4 & 7 \\
\hline $\begin{array}{l}\text { Iva imbricata Walt. Marsh elder } \\
\text { Caldium jamaicensis Crantz. }\end{array}$ & & 5 & 4 \\
\hline Saw grass & & 6 & 9 \\
\hline $\begin{array}{l}\text { Spartina patens (Ait.) Muhl. } \\
\text { Salt meadow grass }\end{array}$ & & & 1 \\
\hline $\begin{array}{l}\text { Baccharis halimifolia } \mathrm{L} \text {. } \\
\text { Sea myrtle }\end{array}$ & & & 3 \\
\hline Pinus taeda L. Loblolly pine & & & 5 \\
\hline Myrica cerifera L. Wax myrtle & & & 6 \\
\hline $\begin{array}{l}\text { Panicum virgatum } \mathrm{L} \text {. } \\
\text { Switch grass }\end{array}$ & & & 8 \\
\hline $\begin{array}{l}\text { Fimbristylis spadices (L.) Vahl. } \\
\text { Marsh sedge }\end{array}$ & & & 10 \\
\hline $\begin{array}{l}\text { Andropogon virginicus } \mathrm{L} . \\
\text { Broom Sedge }\end{array}$ & & & 11 \\
\hline Rhus radicans L. Poison Ivy & & & 12 \\
\hline Ilex vomitorea Ait. Yaupon & & & 13 \\
\hline $\begin{array}{l}\text { Persea borbonia (L.) Spreng. } \\
\text { Red-bay }\end{array}$ & & & 14 \\
\hline $\begin{array}{l}\text { Gelsemium sempervirens (L.) } \\
\text { Ait. Yellow jassamine }\end{array}$ & & & 15 \\
\hline
\end{tabular}

\footnotetext{
a Scattered in southwest margins of marsh.

b Occurred in one small patch on higher ground in center of marsh.
}

area to the river. An adjoining area of the marsh was left undisturbed by the drag lines. During the latter part of April 1972, a series of samples of the marsh sod were removed from the undisturbed section of the marsh and washed to recover larvae of Tabanidae. The grid system was utilized for sampling with $5 \mathrm{~m}$ between samples. It was not until July (the height of the adult tabanid season) that soil samples were removed from the ditched area of the North River salt marsh. Five transects were established at right angles to the parallel ditches and spaced $20 \mathrm{~m}$ apart. Five samples were taken along each transect with the samples on either end located on the margins of the ditch; the samples between were approximately $13 \mathrm{~m}$ apart.

\section{Davis Peninsula Marsh}

The Davis Peninsula study area was an extensive marsh dominated by Juncus roemerianus. The marsh proper occupied an area approximately 1.0 mile wide and 1.5 miles long. The marsh lies south of the township of Davis and is bordered by Core Sound to the East and Jarrett Bay to the West. The entire marsh had been drag-line ditched at 45-m intervals for mosquito control. The Juncus vegetation was very dense with the exception of the borders of a few natural drainage ditches. These ditches were characterized by $S$. alterniflora and $D$. spicata.

In this extensive marsh we attempted to sample in areas which were representative of the various transitions in terrain. Short paired transects were established in the areas of natural drainage extending from the waters edge into the dense $J$. roemerianus vegetation. In the areas of pure $J$. roemerianus which had been ditched, transects were established at right angles to the existing ditch.

Sampling was also done within a $J$. roemerianus marsh which was isolated within the large stand of hardwoods. The only connection of this marsh and the large marsh proper was a drainage ditch extending through the wooded area.

\section{Results and Discussion}

The number and species of tabanid larvae recovered from the various vegetative types are shown in Table 3 ,

In our sampling areas in North Carolina, larval tabanidae were distributed throughout the lower salt marshes occurring in highest densities in areas below mean high tides and dominated by $S$. alterniflora. Although ditches, both natural and man-made, were prominent in the areas, their effects on larval tabanid populations were apparently reduced or negated by the degree and regularity of tidal inundation over the entire lower salt marsh.

Larvae of Chrysops fuliginosus were recovered from all dominant vegetative types, but greater densities were found in areas flooded twice daily by high tides and dominated by $S$. alterniflora. Although only 6 specimens of $C$. atlanticus were identified, all were found in $S$. alterniflora, mostly in open marsh slightly below mean high tide and dominated by dense growth of short $S$. alterniflora. Sixty percent of the identified specimens of $T$. nigrovittatus were the varient called " $T$. sp. 3" by Freeman and Hansens (1972) and " $T$. sp. A" by Jamnback and Wall (1959). This varient of $T$. nigrovittatus is distinguishable in the larval stage but not in the adult stage. Half of the remaining $40 \%$ were identified as adults and therefore differentiation of the varient from typical $T$. nigrovittatus was not possible. Like C. fuliginosus, Tabanus larvae were recovered from all vegetative types with greater densities occurring in lower areas dominated by tall form S. alterniflora and regularly inundated by tide waters.

It is clear from our data, and other published reports, that the common coastal species of Tabanidae have their larval stages in the soil of the salt 
Table 2.-Marsh elevations in relation to tide levels at representative points in vegetative types in Newport River Marsh, Carteret County, North Carolina. 1972.

\begin{tabular}{|c|c|c|c|c|c|c|c|c|c|c|c|c|c|}
\hline \multirow[b]{2}{*}{ Vegetation } & \multirow{2}{*}{$\begin{array}{l}\text { Grid } \\
\text { no. }\end{array}$} & \multicolumn{12}{|c|}{ Marsh level in feet above $(+)$ or below $(-)$ monthly mean high tide } \\
\hline & & March & April & May & June & July & Aug. & Sept. & Oct. & Nov. & Dec. & Jan. & Avg \\
\hline $\begin{array}{l}\text { Spartina alterniflora } \\
\text { (tall form) }\end{array}$ & B 2 & -.32 & -.27 & -.53 & -.67 & -.09 & -.98 & -.87 & -.84 & -.69 & -.51 & -.65 & -.58 \\
\hline $\begin{array}{l}\text { Spartina alterniflora } \\
(\text { short form })\end{array}$ & F 4 & -.14 & -.09 & -.35 & -.49 & +.09 & -.80 & -.69 & -.66 & -.51 & -.33 & -.47 & -.40 \\
\hline Distichlis spicata & E 8 & +.38 & +.43 & +.17 & +.03 & +.61 & -.28 & -.17 & -.14 & +.01 & +.19 & +.05 & +.12 \\
\hline Juncus roemerianus & I 7 & +.16 & +.21 & -.05 & -.19 & +.39 & -.50 & -.39 & -.36 & -.21 & -.03 & -.17 & -.10 \\
\hline Spartina cynosuroides & D 5 & +.34 & +.39 & +.13 & -.01 & +.57 & -.32 & -.21 & -.18 & -.03 & +.15 & +.01 & +.08 \\
\hline
\end{tabular}

marshes. The relative tabanid productivity of a marsh can be estimated from observations on the tides and the vegetation (compare table 2 and 3 ). The greatest abundance of tabanid larvae is in the regularly flooded low marshes with Spartina alterniflora the dominant vegetation, and the larvae are distributed throughout these marshes. The abundance of larvae decreases progressively towards the slightly higher elevations with concurrent decrease in Spartina and increase in the irregularity of flooding. However, even in the high Juncus marsh there can be some larvae, particularly in interspersed patches

Table 3.-Recovery of tabanid from soil in various plant associations in 4 salt marshes in Carteret County, N.C. 1972.

\begin{tabular}{|c|c|c|c|c|c|c|c|}
\hline \multirow[b]{2}{*}{ Vegetation } & \multicolumn{2}{|c|}{ Samples } & \multicolumn{2}{|c|}{ Larvae } & \multicolumn{3}{|c|}{ Species and no. identified } \\
\hline & $\begin{array}{c}\text { Total } \\
\text { no. }\end{array}$ & $\begin{array}{l}\% \text { with } \\
\text { larvae }\end{array}$ & $\begin{array}{c}\text { Total } \\
\text { no. }\end{array}$ & $\begin{array}{c}\text { Avg/ } \\
\text { sample }\end{array}$ & $\begin{array}{l}\text { C. fuligi- } \\
\text { nosus }\end{array}$ & $\begin{array}{l}\text { C. atlan- } \\
\text { ticus }\end{array}$ & $\begin{array}{c}T \text {. nigro- } \\
\text { vittatus }\end{array}$ \\
\hline \multicolumn{8}{|c|}{ Newport River } \\
\hline Spartina alterniflora & 179 & 77.1 & 521 & 2.95 & 65 & 4 & $20^{\mathrm{a}}$ \\
\hline Distichlis spicata & 27 & 25.9 & 12 & .44 & 5 & 0 & $1^{\mathrm{b}}$ \\
\hline Juncus roemerianus & 47 & 26.1 & 29 & .62 & 11 & 0 & $1^{\mathrm{c}}$ \\
\hline S. cynosuroides & 13 & 53.8 & 17 & 1.31 & 1 & 0 & $3^{\mathrm{b}}$ \\
\hline S. alt. $+D$. spic. & 15 & 46.7 & 14 & .93 & 3 & 1 & 0 \\
\hline J. roem. + D. spic. & 5 & 40.0 & 7 & 1.40 & 4 & 0 & 0 \\
\hline Totals and overall avg & 286 & 44.9 & 600 & 1.28 & 89 & 5 & 25 \\
\hline \multicolumn{8}{|c|}{ Hoop Hole Creek } \\
\hline Spartina alterniflora & 11 & 36.4 & 6 & .54 & 3 & 0 & 0 \\
\hline Juncus roemerianus & 14 & 7.1 & 1 & .07 & 0 & 0 & 0 \\
\hline S. alt. + D. spic. & 5 & 40.0 & 3 & .60 & 0 & 0 & $2^{\mathrm{d}}$ \\
\hline S. alt. $+J$. roem. & 5 & 40.0 & 3 & .60 & 2 & 0 & 0 \\
\hline S. alt. + D. spic + J. roem. & 5 & 40.0 & 2 & .40 & 0 & 0 & 0 \\
\hline None & 3 & 0 & 0 & 0 & 0 & 0 & 0 \\
\hline Totals and overall avg & 43 & 27.2 & 15 & 0.37 & 5 & 0 & 2 \\
\hline \multicolumn{8}{|c|}{ North River } \\
\hline Juncus roemerianus & 16 & 50.0 & 14 & .87 & 10 & 0 & 0 \\
\hline S. alt. + J. roem. & 4 & 50.0 & 6 & 1.50 & 4 & 0 & 0 \\
\hline Totals and overall avg & 20 & 50.0 & 20 & 1.19 & 14 & 0 & $\overline{0}$ \\
\hline \multicolumn{8}{|c|}{ Davis Peninsula } \\
\hline Spartina alterniflora & 10 & 40.0 & 5 & .50 & 1 & 1 & 0 \\
\hline Distichlis spicata & 6 & 16.7 & 1 & .17 & 0 & 0 & 0 \\
\hline Juncus roemerianus & 37 & 16.0 & 7 & .19 & 1 & 0 & $2^{\mathrm{e}}$ \\
\hline S. alt + D. spic. & 4 & 0 & 0 & 0 & 0 & 0 & $2^{\mathrm{c}}$ \\
\hline$S$. alt. + J. roem. & 2 & 50.0 & 1 & .50 & 0 & 0 & 0 \\
\hline J. roem.$+D$. spic. & 14 & 28.6 & 7 & .50 & 0 & 0 & $5^{\mathrm{f}}$ \\
\hline S. alt + D. spic. + J roem & 4 & 25.0 & 1 & .25 & 0 & 0 & 0 \\
\hline None & 16 & 0 & 0 & 0 & 0 & 0 & 0 \\
\hline Totals and overall avg & 93 & 22.0 & 22 & 0.26 & 2 & 1 & $\overline{9}$ \\
\hline
\end{tabular}

a Includes 3 "T. sp. 3" larvae identified by Freeman, 13 "T. sp. 3 or A" larvae identified by Teskey, 4 identified as adults by Dukes. b Identified as " $T$, sp. 3" larvae by Teskey.

c Identified by Teskey.

dentified as adults by Dukes.

Includes 1 " $T$. sp. 3" larvae identified by Teskey.

${ }^{f}$ Includes 1 adult identified by Dukes and 4 larvae identified by Teskey. 
of other vegetation, which are indicative of frequent flooding. Thus, in these high marshes, tabanid larvae are less uniformly distributed than they are in the low Spartina marshes.

These generalities can be useful in evaluation of the potential tabanid pest problem in an area. Recovery of the larvae from the marsh sod is extremely laborious and using vegetation type and extent as indicators of tabanid breeding is a practical short-cut. Aerial color photography for detection of vegetative types is under development and if perfected will greatly expedite the detection of breeding areas for tabanids, as well as mosquitoes.

These characteristics of tabanid larval distribution in the coastal salt marshes suggest that any control measures (Wall and Marganian 1973) directed against the immature stages would be inadvisable because such measures would have to be applied to vast expenses of marshes which are important sources of nutrients for estuarine organisms. It could be argued that if a chemical agent (insecticide, growth inhibitor, etc.) or a biological agent is found that is specific for these tabanid larvae then larval control in the marshes will be feasible. Whether or not this is true depends on the future development of a specific agent and a more adequate knowledge of the consequences of removing a large part of the population of these insect larvae from the marsh ecosystem.

The role of tabanids (and other insects) in the marsh ecosystem is poorly understood (Cameron 1972, Marples 1966, Teal 1962, Weiss and West 1924). Most studies have concentrated on collection of the adult stages of insects in the marsh and these investigations are few and limited. The time of day and time of year when collections of adults are made are very important in determining the species and numbers collected and these factors have not always been given due consideration. For example, adult tabanids and Culicoides move quickly from the marsh to the upland during certain periods of the day after emergence and the various species have distinct periods of activity during the year. Even less is known about the larval stages in the ecosystem. The numbers of recovered insect larvae in ecological studies is usually low and this is understandable due to the difficulties involved. Our recovery of tabanid larvae in the Spartina marsh averaged about 3 per $0.1 \mathrm{~m}^{2}$ (or about 140,000 per acre) and our method probably recovered $50 \%$ or less of the actual number. Time of year that samples are taken is critical. We were able to recover appreciable numbers of large tabanid larvae in the spring (April), but we could recover only a few at other times. In other studies in progress, we are finding extremely high numbers of Culicoides (Ceratopogonidae) larvae in the marsh soil. These tabanids and Culicoides larvae are primary consumers. Their precise feeding habits are not known, but we assume that many species are feeding on detritus, algae, bacteria, etc. in the marsh soil. In addition, the larvae of many species of greenheads (Tabaninae) are cannibalistic and carnivorous. Conclusions on the contribution of insects to the energy budget of marshes differ among investigators (McMahan et al. 1972, Teal 1962). More data are needed and, in particular, there should be more attention given to the larval stages of insects in the marsh soil.

Until the above problems are better understood, control of pest species of salt marsh Tabanidae (and Ceratopogonidae as well) should be accomplished by methods which will present minimal hazard to the marsh ecosystem. In some circumstances, traps may be used but these collect large numbers of only certain species, especially $T$. nigrovittatus and closely related species. Barrier plantings of shrubs and trees can interfere with movement of the tabanids from the marsh to the upland areas. Selective applications of short-lived insecticides against the adult insects in the upland areas where the flies are annoying people and animals, can provide temporary control. Most importantly, efforts should be made by planners to avoid human habitation excessively close to the types of marshes which produce these flies. These, and other approaches, should be integrated in a management program tailored to the pest problem in a given area (Gerhardt et al. 1973).

\section{REFERENCES CITED}

Adams, D. A. 1963. Factors influencing vascular plant zonation in North Carolina salt marshes. Ecology 44: 445-56.

Bailey, N. S. 1948. A mass collection and population survey technique for larvae of Tabanidae (Diptera). Bull. Brooklyn Entomol. Soc. 43: 22-9.

Cooper, A. W. 1969. Salt Marshes, p. 567-611. In H. T. Odum, B. J. Copeland and E. A. McMahan (Ed.), Coastal Ecological Systems of the United States, A source book for estuaring planning, Vol. 1. Institute of Marine Sciences, University of North Carolina.

Cameron, G. N. 1972. Analysis of insect trophic diversity in two salt marsh communities. Ecology 53: 58-73.

Davis, L. V., and I. E. Gray. 1966. Zonal and seasonal distribution of insects in North Carolina salt marshes. Ecol. Monogr. 36: 275-95.

Dukes, J. C., T. D. Edwards, and R. C. Axtell. 1974. Distribution of larval Tabanidae (Diptera) in a Spartina alterniflora salt marsh. J. Med. Entomol. 11(1): 79-83.

Edwards, T. D., J. C. Dukes, and R. C. Axtell. 1974. Soil-washing apparatus for recovery of tabanid larvae and other invertebrates. J. Georgia Entomol. Soc. 9(1): (In press.)

Freeman, J. V., and E. J. Hansens. 1972. Collecting larvae of the salt marsh greenhead Tabanus nigrovittatus and related species in New Jersey: Comparison of Methods. Environ. Entomol. 1: 653-8.

Gerhardt, R. R., J. C. Dukes, J. M. Fálter, and R. C. Axtell. 1973. Public opinion on insect pest management in coastal North Carolina. N. C. Agric. Ext. Serv. Misc. Publ. No. 97: 81 p.

Jamnback, H., and W. Wall. 1959. The common salt marsh Tabanidae of Long Island, New York. New York State Mus. Sci. Serv. Bull. 375: 77 p.

Jones, C. M., and D. W. Anthony. 1964. The Tabanidae (Diptera) of Florida. U.S. Dep. Agric. Tech. Bull. 1295: 85 p. 
Marples, T. G. 1966. A radionuclide tracer study of arthropod food chains in a Spartina salt marsh ecosystem. Ecology 47: 270-7.

McMahan, E. A., R. L. Knight, and A. R. Camp. 1972. A comparison of microarthropod populations in sewage-exposed, and sewage-free Spartina salt marshes. Environ. Entomol. 1: 244-52.

Mooring, M. T., A. W. Cooper, and E. D. Seneca. 1971. Seed germination and evidence for height ectophenes in Spartina alterniflora from North Carolina. Am. J. Bot. 58: 48-55.

Pechuman, L. L. 1972. The horse flies and deer flies of New York (Diptera: Tabanidae). Search (Cornell U. Agric. Exp. Stn.) 2(5): 72 p.

Perkins, S. O. 1938. Soil survey of Carteret County, North Carolina, U.S. Dep. Agric. Sur. Chem. Soils, No. 3: 34 p.

Roberts, R. H. 1966. A technique for rearing the immature stages of Tabanidae (Diptera). Entomol. News 77: 79-82.

Rockel, E. G. 1969. Marsh physiography: influence on distribution of intertidal organisms, Proc. N. J. Mosq. Extermin. Assoc. 56: 102-15.

Rockel, E. G., and E. J. Hansens. 1970a. Emergence and flight activity of salt marsh horse flies and deer flies. Ann. Entomol. Soc. Am. 63: 27-31. 1970b. Distribution of larval horse flies and deer flies (Diptera: Tabanidae) of a New Jersey salt marsh. Ibid. 63: 681-4.

Teal, J. M. 1962. Energy flow in the salt marsh ecosystem of Georgia. Ecology 43: 614-24.

Teskey, H. J. 1962. A method and apparatus for collecting larvae of Tabanidae (Diptera) and other invertebrate inhabitants of wet lands. Proc. Entomol. Soc. Ont. 92: 204-6.

1969. Larvae and pupae of eastern North American Tabanidae (Diptera). Entomol. Soc. Can. Mem. 63: $147 \mathrm{p}$

Wall, W., and H. Jamnback. 1957. Sampling methods used in estimating larval reproduction of salt marsh Tabanids. J. Econ. Entomol. 50: 389-91.

Wall, W. J., Jr., and O. W. Doane, Jr. 1960. A preliminary study of the bloodsucking Diptera on Cape Cod, Massachusetts. Mosq. News 20: 39-44.

Wall, W. J., Jr., and V. M. Marganian. 1973. Control of salt marsh Culicoides and Tabanus larvae in small plots with granular organophosphorus pesticides, and the direct effect on other fauna. Ibid. 33 : $88-93$.

Weiss, H. B., and E. West. 1924. The insects and plants of a salt marsh on the coastal plain of New Jersey. J. N.Y. Entomol. Soc. 32: 93-104.

Reprinted from the

ENVIRONMENTAL ENTOMOLOGY 